\title{
PENGEMBANGAN MULTIMEDIA PEMBELAJARAN INTERAKTIF BERBASIS ADOBE FLASH CS4 PROFESIONAL PADA MATA PELAJARAN KIMIA SMA
}

\author{
Jumasari Siregar \\ Pendidikan Kimia, Program Pascasarjana, Universitas Negeri Medan \\ J1. Willem Iskandar Pasar V, Medan, Indonesia \\ siregarjumasari@gmail.com
}

\begin{abstract}
ABSTRAK
Pembelajaran merupakan proses komunikasi antara guru dan siswa. Dalam proses komunikasi khususnya kegiatan belajar mengajar sangat diperlukan adanya media dan alat bantu untuk mencapai tujuan pembelajaran. Media dalam pembelajaran berperan sebagai alat untuk menyampaikan pesan informasi dari guru kepada siswa sehingga kegiatan pembelajaran menjadi interaktif. Tujuan penelitian ini adalah pengembangan pembelajaran multimedia interaktif pada pembelajaran kimia SMA dengan menggunakan program Adobe Flash CS4 Profesional. Manfaat utama dari pengembangan multimedia ini adalah untuk bidang pendidikan sebagai media pembelajaran interaktif khususnya mata pelajaran kimia di SMA. Sebagai penelitian pengembangan, penelitian ini menggunakan model pengembangan ADDIE. Ada lima tahapan utama dalam penelitian ini, yaitu tahapan analisis, desain, pengembangan, implementasi, dan evaluasi. Produk terlebih dahulu divalidasi oleh tim ahli media dan ahli materi. Setelah divalidasi, multimedia ini diujicobakan dalam kelompok kecil. Hasil uji coba menunjukkan 80,7\% layak digunakan, sehingga multimedia interaktif ini menjadi kategori layak dan baik untuk pembelajaran kimia di SMA.
\end{abstract}

Kata kunci : Multimedia interaktif, Adobe Flash CS4 Profesional, ADDIE

\begin{abstract}
Learning is a process of communication between teachers and students. In the communication process, especially teaching and learning activities, it is necessary to have media and tools to achieve the learning objectives. Media in learning acts as a tool to convey information messages from teachers to students so that learning activities have become interactive. The purpose of this research is the development of interactive multimedia learning in high school chemistry learning using the Adobe Flash CS4 Professional program. The main benefit of developing this multimedia is for the field education as an interactive learning medium, especially chemistry subjects in high school. As development research, this research uses the ADDIE development model. There are five main stages in this research, namely the stages of analysis, design, development, implementation, and evaluation. The product was first validated by a team of media experts and material experts. After being validated, this multimedia was tested in small groups. The results of the trial showed that $80.7 \%$ was suitable for use, so this interactive multimedia became a feasible category for learning chemistry in high school.
\end{abstract}

Key Word: Interactive multimedia, Adobe Flash CS4 Professional, ADDIE

\section{PENDAHULUAN}

Diawal tahun 2020, penyebaran dan penularan Virus Corona (Covid-19) semakin merebak diseluruh penjuru dunia. Pandemi yang awal penularannya berasal dari Wuhan ini terus meluas dan tak terkendali. Tak terkecuali dengan Indonesia (Basri, 2021), sehingga Indonesia saat ini sedang dalam ujian terbesar sepanjang sejarah (Retnaningsih, 2020). Pada masa pandemi Covid-19 ini, banyak terjadinya hal-hal yang mempengaruhi dalam setiap bidang pergerakan, terutama dalam bidang kesehatan. Hal ini juga berdampak besar pada bidang pendidikan. Maka, dengan keadaan seperti ini para instansi maupun lembaga mengambil tindakan agar mengurangi risiko terhadap Covid-19. Terlihat bagaimana proses pendidikan yang menjadi terhambat secara langsung dalam melakukan prosesnya di sekolah (Aulia, 2021).

Kondisi ini mengharuskan semua elemen pendidikan untuk beradaptasi kebiasaan Baru ( AKB ) Pembelajaran daring (online) menjadi pilihan agar kegiatan belajar mengajar tetap terlaksanakan. Namun, teknik pembelajaran ini perlu diberikan evaluasi 
agar sesuai dengan yang diharapkan dengan kondisinya. Karena fasilitas sekolah dan kemampuan orang tua dalam keterlibatan pembelajaran online berbeda kepada peserta didik di Indonesia (Nurdin, 2021). Salah satunya dengan menggunakan multimedia yang interaktif. Multimedia interaktif merupakan paduan berbagai jenis fungsi media yaitu suara, video, animasi, photo, dan tulisan yang digabung menjadi satu sehingga bersifat interaktif. Dengan kelebihan multimedia interaktif tersebut, sehingga berpotensi dijadikan media pembelajaran (Koesnandar, 2019).

Salah satu software yang berbasis animasi adalah media interaktif dalam pembelajaran. Pembelajaran menggunakan animasi komputer memungkinkan siswa untuk belajar secara dinamis dan interaktif. Adobe Flash adalah standar program aplikasi yang digunakan dalam pembuatan animasi vektor dan animasi gambar yang luar biasa untuk keperluan pembuatan website yang interaktif dan dinamis. Aplikasi ini diimplementasikan sebagai media belajar. Pesan yang disampaikan melalui media, berupa isi atau bahan ajar yang harus diterima oleh siswa, dengan menggunakan kombinasi dari beberapa alat inderanya. Lebih baik lagi, ketika semua perangkat penginderaan yang dimiliki mampu menyerap informasi yang diterima (Supriyadi, 2016).

Ilmu kimia mengkaji segala bentuk materi yang ada di alam. Siswa dituntut untuk memiliki kompetensi memahami konsep teori, memahami fakta, serta memahami hukum prinsip teori kejadian-kejadian yang ada di alam secara matang, sehingga siswa dapat mengimplementasikan ilmu tersebut dalam kehidupan sehari-hari. Dengan kata lain kimia adalah kelompok mata pelajaran yang membahas fenomena-fenomen alam seperti komponen, cara kerja suatu sistem dan unsur-unsur yang terkandung di dalam sistem tersebut. Diharapkan dengan adanya pengetahuan ini siswa dapat memecahkan permasalahan yang ditemui dalam kehidupan sehari-hari (Putri, 2021).

Tingkat pemahaman siswa terhadap konsep dasar kimia memberi peranan penting untuk hasil belajar siswa yang maksimal menuju konsep yang lebih tinggi (Zakiyah, Ibnu \& Subandi, 2018). Hasil belajar siswa juga akan dipengaruhi oleh beragam faktor eksternal yang terdapat di lingkungan belajar, salah satunya adalah media pembelajaran (Pratiwi \& Meilani, 2018), terkhusus kondisi pandemi Covid-19 yang masih berlangsung. Serta pemilihan strategi, metode media bantu belajar dan sumber belajar harus efektif dan efisien, serta tepat digunakan untuk menunjang pembelajaran sesuai dengan karakteristik materi dan karakteristik siswa (Degeng dalam putri, 2021, h.2).

Dalam (Sari \& Sawila 2019) penggunaan software adobe flash memiliki validasi dan efektivitas/respon yang baik dari siswa dengan hasil sebesar 85 dan 86,8 persen. Berdasarkan kondisi yang dijelaskan diatas maka penelitian ini bertujuan untuk pengembangan multimedia pembelajaran interakitf berbasis adobe flash CS4 profesional pada mata pelajaran kimia SMA. Penelitian ini diharapkan akan dapat memberikan informasi dan manfaat pengembangan multimedia pembelajaran interakitf berbasis adobe flash CS4 profesional pada mata pelajaran kimia SMA, Khususnya semasa pandemi Covid-19 kepada pembaca. Sehingga, pembaca dapat juga menjadikan referensi untuk penelitian lanjut yang lebih baik dalam penerapan pembelajaran kimia SMA

\section{METODE PENELITIAN}

Penelitian ini menggunakan model penelitian pengembangan (research and development) dan design pengembangan yang digunakan adalah model pengembangan ADDIE. Model ADDIE yaitu analis (analysis), desain (design), pengembangan (development), Pelaksanaan (Implementation), dan Evaluasi (Evaluation). Menurut (Mulyatiningsih, 2016) Model ADDIE digunakan untuk berbagai macam pengembangan produk dalam kegiatan pembelajaran seperti bahan ajar dan media. 


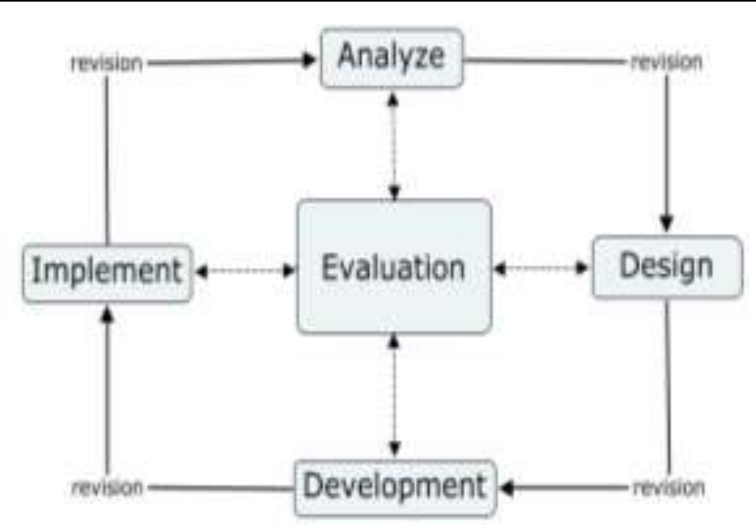

Gambar 1 . Design Model ADDIE

Pada tahap analisis dilakukan analisis karakter siswa dan analisis tujuan. Analisis karakter siswa bertujuan untuk mengetahui tingkat latar belakang perkembangan kognitif, latar belakang pengetahuan dan latar belakang sosial budaya sehingga setelah dilakukannya analisis ini selanjutnya penyusunan materi pembelajaran yang cocok untuk subjek penelitian. Subjek penelitian ini yaitu siswa/i SMA dengan kisaran usia 15-17 tahun. Setelah analisis selesai, dilanjutkan dengan perancangan desain media yang akan dibuat. Tahap design pada pengembangan ini meliputi jadwal, team, spesifikasi produk, struktur materi dan evaluasi.

Langkah selanjutnya adalah Development dan Implement, yaitu mengumpulkan bahanbahan yaang diperlukan dalam pembuatan produk sesuai dengan desagn yang telah dibuat. Kemudian pembuatan produk (multimedia pembelajaran) dengan dibantu oleh software adbe flash CS4 profesional. Setelah produk selesai, selanjutnya produk tersebut divalidasi oleh validator (ahli materi dan ahli media). Setelah dilakukan validasi dan validator menyatakan produk layak diujicobakan, kemudian melakukan ujicoba produk kepada subjek, dalam hal ini subjek yang dituju yaitu siswa SMA kelas XI. Dan uji coba yang dilakukan hanya sebatas ujicoba pada kelompok kecil saja. Pengambilan subjek penelitian ini dilakukan secara acak dengan kemampuan yang berbeda-beda.

Tahap terakhir adalah Evaluasi, yaitu proses untuk melihat apakah sistem pembelajaran yang diterapkan sesuai tujuan yang diinginkan atau gagal. Hal tersebut dilihat dari hasil pengisian angket siswa dan suasana belajar siswa pada saat media tersebut digunakan sewaktu uji coba produk .
Dalam penelitian pengembangan ini, jenis data yang dikumpulkan adalah data kuantitatif dan kualitatif. Data kuantitatif diambil dari penilaian siswa terhadap pembelajaran menggunakan multimedia dengan Adobe Flash CS4 Profesional yang diterapkan. Data kualitiatif diperoleh melalui pengisian angket oleh tim validasi yaitu tim ahli media dan materi. Dari hasil angket juga diperoleh saran perbaikan guna penyempurnaan multimedia pembelajaran interaktif ini.

Instrumen pengambilan data penelitian ini menggunakan angket dan lembar observasi. Angket digunakan untuk memperoleh data kuantitatif dan kualitiatif. sedangkan lembar observasi dibuat untuk mengetahui kemampuan siswa dalam mengoperasikan multimedia pembelajaran kimia. Angket yang digunakan berupa angket tertutup dan angket terbuka. Angket terbuka diberikan kepada siswa untuk melihat sikap dan respon siswa mengikuti pelajaran kimia khususnya teori asam basa menggunakan media tersebut. Angket tertutup diberikan kepada tim ahli materi dan media yang untuk mengetahui tingkat validitas media melalui pengumpulan data yang dilihat melalui saran-saran yang ada. Data dari pengisian angket tim ahli selanjutnya dianalisis secara deskriptif.

\section{HASIL DAN PEMBAHASAN}

Tahapan pembuatan multimedia pembelajaran interaktif terdiri dari; analisis kebutuhan, dilanjutkan pemilihan topik pembelajaran yang sesuai, penyusunan garis besar isi materi pembelajaran, penulisan naskah dan batasannya, pelaksanaan produksi, evaluasi dan revisi, serta pengemasan produk media (Koesnandar, 2019). Lalu didesain dengan pengembangan ADDIE sifatnya lebih generik (Analysis-Design-DevelopmentImplement-Evaluate).

Tahap Analysis. Melalui Hasil observasi dilapangan menyatakan bahwa siswa SMA pada umumnya memiliki karakteristik pembelajaran yang mudah bosan dan menganggap pelajaran kimia sulit untuk dipahami. Hasil wawancara dengan siswa juga menyatakan bahwa siswa sangat kesulitan untuk memahami pelajaran kimia dan menganggap kimia itu merupakan pelajaran yang sangat ditakuti. Pada umumnya siswa lebih menyukai pembelajaran 
menggunakan media untuk memahami suatu konsep dalam pelajaran karena mereka dapat melihat langsung visualisasinya. Oleh karena itu, pengembangan multimedia pembelajaran interaktif yang berisikan animasi sangat membantu dan efektif untuk siswa dalam memahami konsep kimia sehingga tujuan pembelajaran dapat dicapai. Selain itu siswa SMA juga telah memiliki kemampuan yang cukup dalam mengoperasikan komputer dan bila media ini diterapkan maka mereka dapat dengan mudah menggunakannya.

Tahap selanjutnya adalah melakukan analisis tujuan yakni tujuan pembelajaran tentang penguasaan kompetensi yang ditargetkan untuk dicapai sesuai dengan Kurikulum. Teori asam basa dipilih menjadi materi yang dikembangkan pada multimedia pembelajaran interaktif karena konsep-konsep dalam teori asam basa sangat memungkinkan dibuat dalam bentuk animasi.

Tahap Design. Pembuatan produk menghabiskan waktu selama 6 bulan (perencanaan, pengumpulan bahan, pembuatan, validasi dan revisi produk). Tim kerja dalam pembuatan media yaitu validator bertugas untuk memvalidasi produk. Peneliti sebagai pembuat produk dan siswa sebagai pengguna dan penilai produk saat dilakukan ujicoba kelompok kecil. Struktur materi dan flowchart disusun berdasarkan prinsipprinsip pembelajaran dan merujuk pada tujuan pembelajaran yang ada pada Kurikulum K13.

Tahap Development and Implemention. Pembuatan multimedia ini menggunakan aplikasi Adobe Flash CS4 Profesional dari halaman pembuka sampai halaman penutup. Multimedia ini terdiri dari halaman pembuka, home, silabus, materi, rangkuman, latihan dan keluar. Desain storyboard yang dihasilkan sebagai berikut :

\section{a. Tampilan Halaman Utama}

Gambar dua ini merupakan halaman utama media yang berisi : (1) Multimedia didesain untuk siswa kelas XI. (2) Judul mater " Teori Asam Basa". (3) Tombol start untuk masuk ke halaman home.

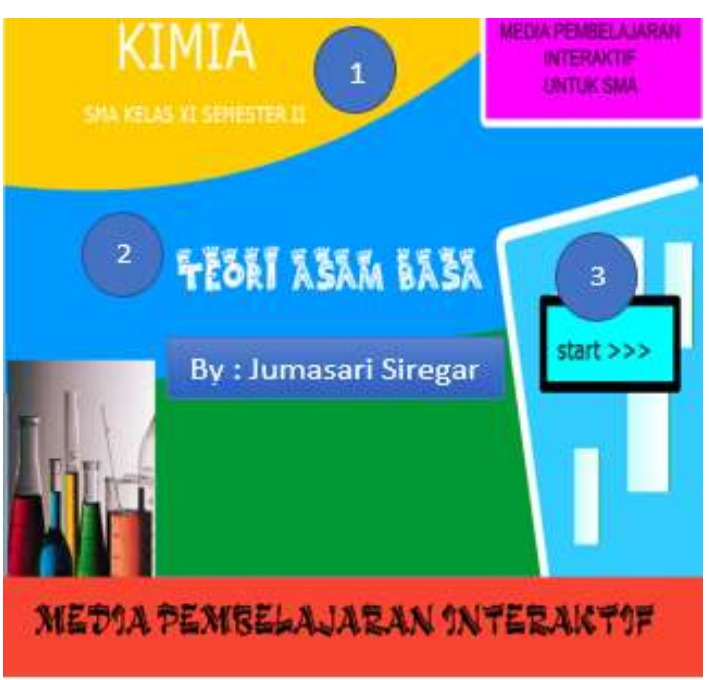

Gambar 2. Tampilan Halaman Utama

\section{b. Tampilan Halaman Home}

Gambar 3 merupakan tampilan halaman home berisikan: (1) Tombol navigasi silabus, materi, rangkuman, dan latihan. Silabus berisikan standar kompetensi (SK), kompetensi dasar (KD), dan indikator pembelajaran yang akan dicapai. Tombol navigasi materi berisi penjelasan tentang materi asam dan basa. Navigasi rangkuman berisi poin-poin penting materi asam basa. Navigasi latihan berisi soal-soal latihan. (2) Gambar yang menunjukkan penggunaan asam basa dalam kehidupan sehari-hari. (3) tombol next yaitu navigasi menuju halaman berikutnya

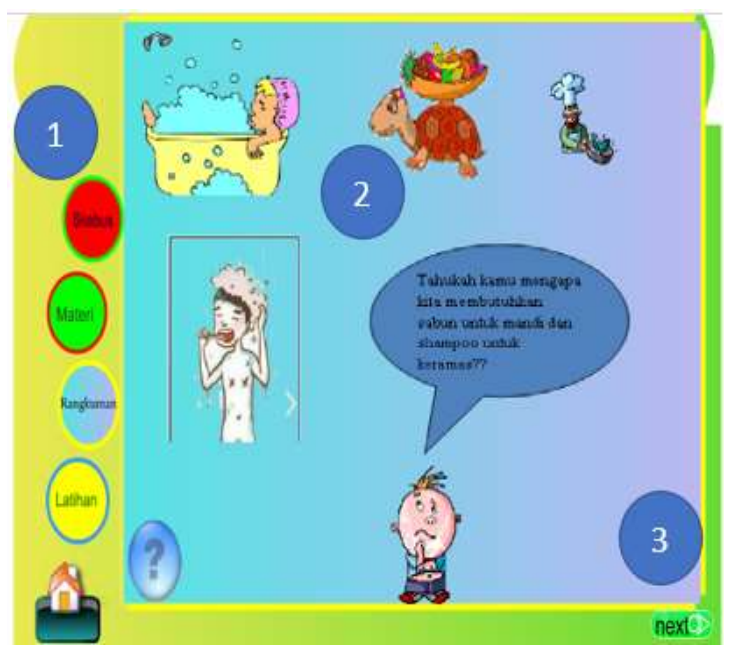

Gambar 3. Tampilan Halaman Home

\section{c. Tampilan Halaman Apersepsi}

Apersepsi merupakan pengamatan awal siswa dari suatu materi pembelajaran untuk menghubungkan suatu kejadian dengan materi yang akan dipelajari. Gambar 4 berisi 
tampilan: (1) Tombol navigasi silabus, materi, rangkuman, dan latihan. (2) Apersepsi tentang teori asam basa. (3) Tombol back untuk kembali ke halaman sebelumnya.

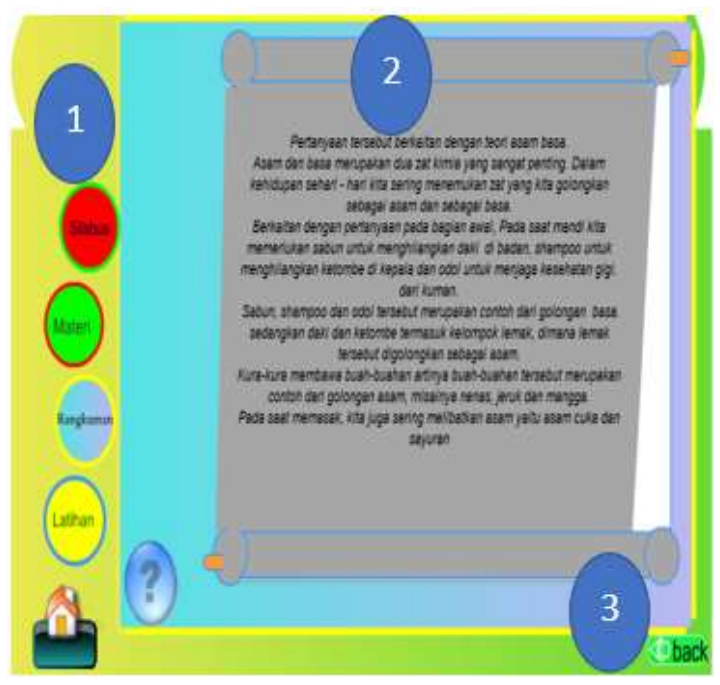

Gambar 4. Tampilan Halaman Apersepsi

Multimedia tersebut divalidasi oleh tim ahli (ahli materi dan ahli media). Ahli materi melakukan validasi sebanyak dua kali. Pada validasi pertama, validator menyarankan untuk menambahkan gambar-gambar bergerak yang berkaitan dengan materi teori asam basa pada bagian halaman pembuka, menambahkan animasi, menambahkan jumlah soal latihan. Pada validasi kedua, validator menyarankan untuk memperbaiki bagian apersepsi dan menyatakan multimedia layak diujicobakan. Ahli media melakukan validasi sebanyak tiga kali.

Pada validasi pertama validator menyarankan untuk membuat SOP, memperbaiki gaya tulisan, pemilihan ukuran dan warna huruf, tombol, membuat animasi yang lebih mudah dimengerti dan kerapian tampilan. Pada validasi kedua validator menyarankan merubah warna tulisan, menyesuaiakan reaksi pada materi dengan animasi, penambahan isi SOP dan memperbaiki tombol yang belum sesuai dengan fungsi sebenarnya. Validasi ketiga, validator hanya memberi saran agar konsep-konsep teori asam basa dibuat lebih kontras agar siswa dapat mengingat poin-poin penting pada teori asam basa dalam waktu lama.

Setelah dilakukan tahap validasi, selanjutnya uji coba kelompok kecil pada siswa kelas XI.
Prosedur ujicoba ini yaitu peneliti menjelaskan dan mempraktekkan cara pemakaian multimedia tersebut, siswa menjalankan multimedia tersebut secara mandiri dari halaman pembuka sampai halaman penutup, siswa mengisi angket "penilaian siswa" dan peneliti mengisi lembar observasi sikap siswa.

Dari hasil pengisian angket siswa dapat disimpulkan bahwa multimedia interaktif teori asam basa termasuk kedalam kategori baik/menarik dengan perolehan skor rata-rata 60,5. Dan persentase yang diperoleh multimedia tersebut adalah 80,7\%. Dengan demikian produk yang dikembangkan dapat dikategorikan menarik serta tanggapan siswa terhadap multimedia yang ditampilkan baik.

Tahap Evaluate. Tahap evaluasi ini yaitu menampung tanggapan dan saran siswa mengenai multimedia interaktif tersebut. Dari komentar dan saran tersebut penulis dapat mengetahui kelemahan multimedia interaktif tersebut di mata siswa, sehingga penulis dapat merevisi multimedia tersebut menjadi lebih bagus dan menarik lagi.

\section{SIMPULAN DAN SARAN}

Penggunaan Adobe Flash CS4 Profesional dalam pengembangan multimedia pembelajaran yang bersifat interaktif sangat layak. Sesuai hasil penelitian ini bahwa Multimedia pembelajaran interaktif khususnya pada mata pelajaran kimia menunjukkan hasil yang memuaskan. Dengan demikian, multimedia pembelajaran interaktif ini efektif jika digunakan sebagai multimedia pembelajaran interaktif kimia. Walau demikian untuk peneliti selanjutnya disarankan dapat melakukan pengembangan dan mengkombinasikan media pembelajaran interaktif yang lebih menarik lagi, seperti animasi berbentuk dimensi, menambahkan tombol navigasi untuk quis sebagai latihan siswa, link sumber belajar tambahan bagi siswa, serta suara. Menerapkan multimedia pembelajaran interaktif menggunakan Adobe Flash CS4 profesional ini juga perlu penambahan materi sehingga multimedia interaktif ini dapat digunakan untuk materi lain di mata pelajaran kimia di SMA. 


\section{UCAPAN TERIMA KASIH}

Penelitian ini dapat terlaksana dengan baik tidak lepas dari bantuan dan keterlibatan beberapa pihak, untuk itu penulis mengucapkan terima kasih kepada Ibu Lince Muis, S.T, M.T dan Bapak Drs. Epinur, M.Si yang telah memberikan kerjasama yang baik dalam penelitian ini.

\section{DAFTAR PUSTAKA}

Aulia, S. (2021). Efektivitas penggunaan media e-Learning di masa pandemi Covid-19 terhadap sikap berpikir kreatif dan kritis siswa. doi:10.31219/osf.io/sv9jk

Basri, M. (2021). Pembelajaran e-Learning Di Masa Pandemi. doi:10.31219/osf.io/rb4p3

Koesnandar, A. (2019). Pengembangan software pembelajaran multimedia interaktif. Jurnal Teknodik, 075-088. doi:10.32550/teknodik.v0i0.548

Mulyatiningsih, E. (2016). Pengembangan model pembelajaran. Retrieved September 30, 2020 from http://staff.uny.ac.id/sites/default/files/ pengabdian/dra-endangmulyatiningsih-mpd/7cpengembanganmodel-pembelajaran.pdf

Nurdin. (2021). Pendidikan dan pembelajaran di masa pandemi Covid-19. doi:10.31219/osf.io/bwsak

Pratiwi, I. T. M., \& Meilani, R. I. (2018). Peran media pembelajaran dalam meningkatkan prestasi belajar siswa. Jurnal Pendidikan Manajemen Perkantoran (JPManper), 3(2), 173181. doi:10.17509/jpm.v3i2.11762

Putri, D. P. E. (2021). Pengembangan multimedia pembelajaran interaktif kimia berbasis android. doi:10.31237/osf.io/5xkbn

Retnaningsih, R. (2020). E-Learning system sebuah solusi pragmatis program vokasional semasa pandemi COVID19. Jurnal Taman Vokasi, 8(1), 21-26. doi:10.30738/Jtv.V8i1.7751

Sari, R. K., \& Sawila, I. (2019, July). Penggunaan Software Adobe Flash CS6 dalam Perancangan Media Pembelajaran Kimia untuk Siswa Kelas X SMA. In Talenta Conference Series: Science and Technology (ST) (Vol. 2, No. 2). doi:10.32734/st.v2i2.543

Supriyadi, S. (2016). ADOBE Flash Untuk Mendukung Pembelajaran. Jurnal Komunikasi, 7(2).

Zakiyah, Z., Ibnu, S., \& Subandi, S. (2018). Analisis Dampak Kesulitan Siswa pada Materi Stoikiometri terhadap Hasil Belajar Termokimia dan Upaya Menguranginya dengan Metode Pemecahan Masalah. EduChemia (Jurnal Kimia dan Pendidikan), 3(1), 119134. doi:10.30870/educhemia.v3il.1784 